American Journal of Applied Sciences 7 (4): 442-446, 2010

ISSN 1546-9239

(C) 2010Science Publications

\title{
Adsorption Study of Electric Arc Furnace Slag for the Removal of Manganese from Solution
}

\author{
${ }^{1}$ C.L. Beh, ${ }^{1}$ Luqman Chuah, ${ }^{1}$ Thomas S.Y. Choong, \\ ${ }^{1}$ Mohd. Zakwan B. Kamarudzaman and ${ }^{2}$ Khalina Abdan \\ ${ }^{1}$ Department of Chemical and Environmental Engineering, \\ ${ }^{2}$ Department of Biological and Agricultural Engineering, \\ Faculty of Engineering, University Putra Malaysia, 43400 Serdang, \\ Selangor DE, Malaysia
}

\begin{abstract}
Problem statement: Steel making slag from Electric Arc Furnace (EAF) is an abundant byproduct in Malaysia steel making industry. It has potential to be used for heavy metal removal from contaminated water or waste water. Approach: The aim of this study was to investigate the characteristic and behavior of manganese removal by using EAF slag for efficient metal removal. The removal characteristics of manganese were investigated in term of sorption kinetics and isotherm. The batch adsorption kinetics and isotherm studies were carried out at $28^{\circ} \mathrm{C}$ and ten grams of EAF slag was added into $1 \mathrm{~L}$ manganese solution of various concentrations of 10, 25, 50, 75, 100 and $120 \mathrm{mg} \mathrm{L}^{-1}$. All these different mixtures were stirred and sampled at various desired times and centrifuged. The supernatant solutions were then collected for chemical analysis. Results: It was found that the EAF slag adsorption kinetics can be described well by the pseudo-2nd order kinetic model with fairly high correlation coefficients. The adsorption process obeyed the Langmuir isotherm model and the maximum uptake of the manganese from the solution is $2.31 \mathrm{mg} \mathrm{L}^{-1} \mathrm{~g}^{-1}$ of EAF slag used. Conclusion: From the study, it was concluded that the EAF slag can be an efficient adsorbent to remove manganese from both the solution and waste water.
\end{abstract}

Key words: Electric arc furnace slag, manganese, sorption kinetics and isotherm, efficient adsorbent

\section{INTRODUCTION}

Human activities in achieving development have caused environmental pollution over the past few decades. One of the major concern of pollutant is heavy metals as they are non-degradable and therefore continue to exist in the water body (Xue et al., 2008a; Ortiz et al., 2000). Since these heavy metals are extremely toxic and does not decay, it may accumulate in human body by the food chain. Therefore, environmental regulation was established in mitigating the heavy metals contamination of the discharge of waste water.

Currently, there are various technologies in removing heavy metals from the waste water namely chemical precipitation, activated carbon adsorption, ion exchange, as well as membrane system. However, all these conventional methods are rather expensive (Kim et al., 2007; Chuah et al., 2004). The Electric Arc Furnace (EAF) slag is a waste material generated from the steel making process. It is an attractive low cost yet effective material for heavy metals removal, particularly manganese removal in waste water treatment process. Manganese is used principally in steel production to improve hardness, stiffness and strength. Manganese is also used in wide variety of other products, including fireworks, dry-cell batteries, fertilizer, paints and cosmetics.

The most common health problems in workers exposed to high levels of manganese involve the nerve system. These health effects include behavioral changes and other nerve system effects, which include movements that may become slow and clumsy.

This combination of symptoms when sufficiently severe is referred to as "manganism". The inhalation or ingestion of a large quantity of manganese content may cause irritation to the lungs which could lead to pneumonia. Loss of sex drive and sperm damage has also been observed in men exposed to high levels of manganese in their body (Kim et al., 2007).

The main objective of this research was to study the use of EAF slag as an effective adsorbent for

Corresponding Author: Thomas S.Y. Choong, Department of Chemical and Environmental Engineering, Faculty of Engineering, University Putra Malaysia, 43400 Serdang, Selangor DE, Malaysia Fax: +603-8656-7120 
manganese removal. The EAF slag used in this study is an industrial waste from the steel mill in Malaysia. This slag is inexpensive and abundant and is therefore ideal for low cost approach of manganese removal from solution or waste water. Generally, EAF slag consist of various metal oxides particularly calcium oxide, silica oxide and ferum oxide. Several researchers have reported the sorption characteristics of the removal of heavy metals from wastewaters using slag (Xue et al., 2008b; Xiong et al., 2007; Nehrenheim and Gustafsson, 2007).

The removal mechanism of adsorption is shown as following (Kim et al., 2007):

$$
>\mathrm{Si}-\mathrm{OH} . . \mathrm{H}-\mathrm{O}-\mathrm{H}\left[\mathrm{Me}\left(\mathrm{OH}_{2}\right)_{3}\right]^{2+} \leftrightarrow>\mathrm{Si}-\mathrm{OMe}+\mathrm{H}_{3} \mathrm{O}^{+}
$$

The adsorption capacity and reactivity of the slag on the manganese was examined by both the batch kinetic and isotherm analysis. The effect of initial metal concentration and the batch contact time were investigated on the metal adsorption by EAF slag.

\section{MATERIALS AND METHODS}

Materials: A set of Electric Arc Furnace (EAF) slag collected from Southern Steel Berhad (Penang, Malaysia) was grinded and sieved to 250 mesh. The EAF slag consists of calcium oxide (45.12\%), silicon dioxide (18.06\%), ferum (II) oxide $(17.73 \%)$, manganese oxide $(5.13 \%)$, aluminum oxide $(4.83 \%)$ and magnesium oxide (4.40\%) (Table 1). The slag sample was cleaned with distilled water and dried in an oven with temperature $100^{\circ} \mathrm{C}$ for $4 \mathrm{~h}$.

Table 1: EAF slag chemical composition (Southern Steel Bhd., 2009)

\begin{tabular}{ll}
\hline Constituent & Composition (\%) \\
\hline $\mathrm{CaO}$ & $36.0-51.4$ \\
$\mathrm{SiO}_{2}$ & $14.0-22.0$ \\
$\mathrm{FeO}$ & $10.6-29.3\left(70-80 \% \mathrm{FeO}, 20-30 \% \mathrm{Fe}_{2} \mathrm{O}_{3}\right)$ \\
$\mathrm{Mn}$ & $2.8-7.3$ \\
$\mathrm{MgO}$ & $3.8-5.2$ \\
$\mathrm{Al}_{2} \mathrm{O}_{3}$ & $3.7-5.7$ \\
$\mathrm{P}_{2} \mathrm{O}_{5}$ & $0.3-1.0$ \\
$\mathrm{~S}$ & $0.1-1.1$ \\
Metallic Fe & $1.4-1.88$ \\
\hline
\end{tabular}

Table 2: Time required reaching equilibrium for different initial concentrations

\begin{tabular}{lll}
\hline Sample & $\begin{array}{l}\text { Initial concentration } \\
\left(\mathrm{m} \mathrm{L} \mathrm{L}^{-1}\right)\end{array}$ & $\begin{array}{l}\text { Equilibrium reached } \\
\text { at }(\mathrm{min})\end{array}$ \\
\hline $\mathrm{a}$ & 10 & 180 \\
$\mathrm{~b}$ & 25 & 240 \\
$\mathrm{c}$ & 50 & 240 \\
$\mathrm{~d}$ & 75 & 240 \\
$\mathrm{e}$ & 100 & 240 \\
$\mathrm{f}$ & 120 & 240 \\
\hline
\end{tabular}

Stock solution of manganese was prepared using manganese sulphate aqueous $\left(\mathrm{MnSO}_{4} \cdot 1 \mathrm{H}_{2} \mathrm{O}\right)$. The concentration of manganese was determined by spectrophotometer before and after the experiment.

Adsorption kinetics: Batch adsorption kinetics studies were carried out at $28^{\circ} \mathrm{C}$ and ten grams of EAF slag was added into $1 \mathrm{~L}$ manganese solution of various concentrations of $10,25,50,75,100$ and $120 \mathrm{mg} \mathrm{L}^{-1}$ (Table 2). All these different mixtures were stirred and sampled at various desired interval time and centrifuged (Hamadi et al., 2004; Wong et al., 2003a). The supernatant solutions were collected for chemical analysis by using spectrophotometer.

Adsorption isotherm: To evaluate the equilibrium and adsorption capacity of slag on manganese, isotherm studies were evaluated at $28^{\circ} \mathrm{C}$ and ten grams of slag was added into $1 \mathrm{~L}$ manganese solution of various concentration of $10,25,50,75,100$ and $120 \mathrm{mg} \mathrm{L}^{-1}$. All these different mixtures were stirred and sampled at desired time and centrifuged (Hamadi et al., 2004; Wong et al., 2003a). The supernatant solutions were collected for chemical analysis by spectrophotometer.

\section{RESULTS AND DISCUSSION}

Adsorption kinetic: Figure 1 shows sorption kinetic results for various initial concentration of manganese solution. A higher initial concentration required more time to reach equilibrium. For manganese solution of initial concentration of $10 \mathrm{mg} \mathrm{L}^{-1}$, the equilibrium was reached after $2 \mathrm{~h}$, solution with initial concentration of $25 \mathrm{mg} \mathrm{L}^{-1}$, the equilibrium is reaching after $3 \mathrm{~h}$ and for solution with concentration of $50,75,100$ and $120 \mathrm{mg} \mathrm{L}^{-1}$, the equilibrium is reached after $4 \mathrm{~h}$.

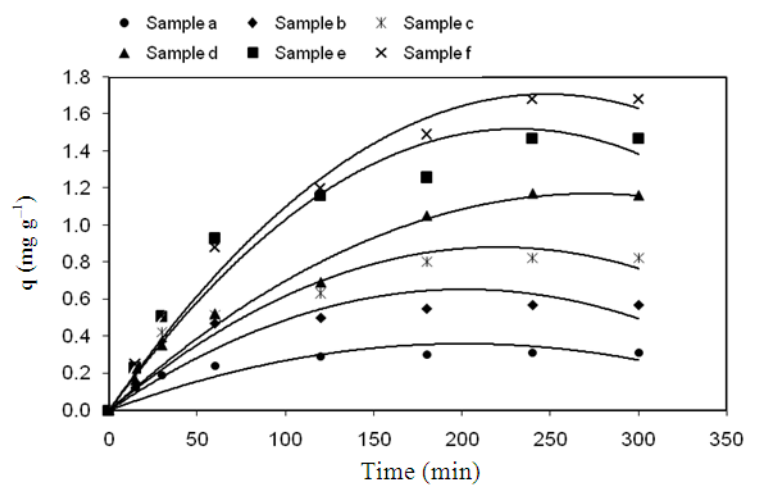

Fig. 1: Adsorption kinetic of various initial concentration of manganese solution at $28^{\circ} \mathrm{C}$ 
The adsorption kinetic data were applied to two kinetics models, i.e. the pseudo first-order and pseudo second-order models. The pseudo first-order kinetics of adsorption (Eq. 2) can be expressed as (Yang, 2003; Tchobanoglous and Burton, 1991):

$\frac{\mathrm{dq}_{\mathrm{t}}}{\mathrm{dt}}=\mathrm{k}_{1}\left(\mathrm{q}_{\mathrm{e}}-\mathrm{q}_{\mathrm{t}}\right)$

where, $\mathrm{q}_{\mathrm{e}}$ and $\mathrm{q}_{\mathrm{t}}\left(\mathrm{mg} \mathrm{g}^{-1}\right)$ are the amount of adsorbed manganese ion at equilibrium and at time $t$, respectively and $\mathrm{k}_{1}\left(\mathrm{~h}^{-1}\right)$ is the first order rate constant.

Equation 2 can be linearized:

$$
\log \left(\mathrm{q}_{\mathrm{e}}-\mathrm{q}_{\mathrm{t}}\right)=\log \mathrm{q}_{\mathrm{e}}-\mathrm{k}_{1} \frac{\mathrm{t}}{2.302}
$$

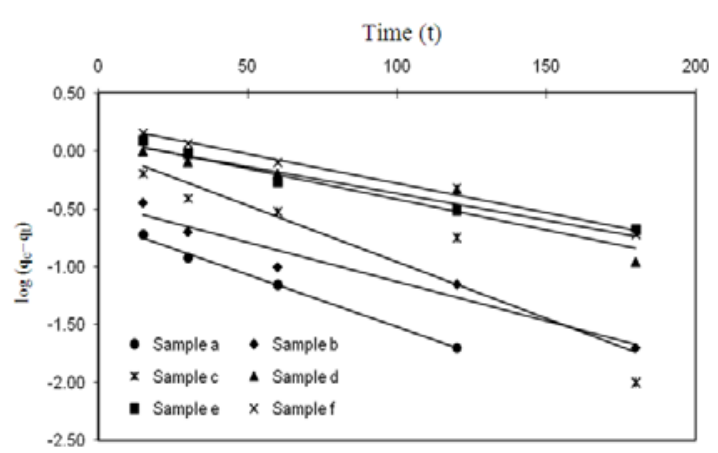

Fig. 2: Pseudo first-order kinetic modeling for various initial concentration of manganese solution

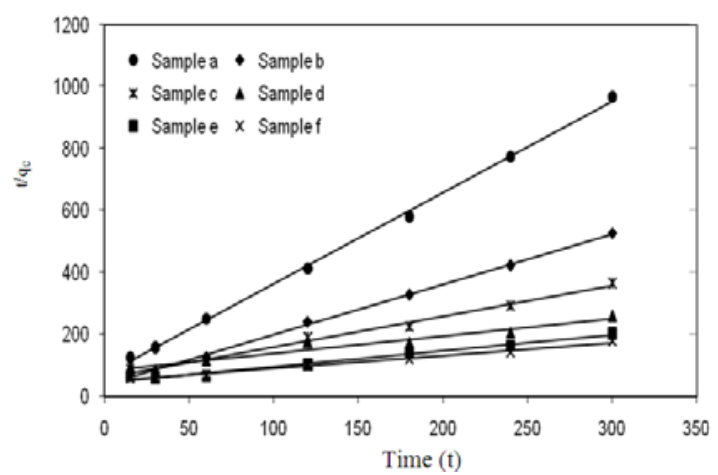

Fig.3: Pseudo second-order kinetic modeling for various initial concentration of manganese solution

Table 3: Parameters of kinetic modeling Pseudo-1st order kinetic model Pseudo-2nd order kinetic model

\begin{tabular}{lllll} 
& & & \\
Sample & $\mathrm{k}_{1}$ & $\mathrm{R}^{2}$ & $\mathrm{k}_{2}$ & $\mathrm{R}^{2}$ \\
\hline $\mathrm{a}$ & 0.021 & 0.996 & 0.124 & 0.998 \\
$\mathrm{~b}$ & 0.014 & 0.948 & 0.068 & 0.998 \\
$\mathrm{c}$ & 0.021 & 0.872 & 0.017 & 0.987 \\
$\mathrm{~d}$ & 0.012 & 0.904 & 0.004 & 0.953 \\
$\mathrm{e}$ & 0.009 & 0.956 & 0.006 & 0.981 \\
$\mathrm{f}$ & 0.012 & 0.988 & 0.004 & 0.990 \\
\hline
\end{tabular}

The pseudo-second order kinetic rate equation is given as:

$$
\frac{\mathrm{dq}}{\mathrm{dt}}=\mathrm{k}_{2}\left(\mathrm{q}_{\mathrm{e}}-\mathrm{q}_{\mathrm{t}}\right)^{2}
$$

where, $\mathrm{k}_{2}\left(\mathrm{~h}^{-1}\right)$ is the second order rate constant.

Equation 4 can be linearized:

$\frac{\mathrm{t}}{\mathrm{q}_{\mathrm{t}}}=\frac{1}{\mathrm{k}_{2} \mathrm{q}_{\mathrm{e}}^{2}}+\frac{1}{\mathrm{q}_{\mathrm{e}}} \mathrm{t}$

The linearized equations are plotted in Fig. 2 and 3. The kinetic parameters are summarized in Table 3. From Table 3, it is found that the EAF slag kinetic adsorption can be described well by the pseudo-2nd order kinetic model with fairly high correlation coefficients.

The EAF slag sample before and after adsorption were also examined by Scanning Electron Microscopic (SEM) to observe morphology of the EAF slag as shown in Fig. 4 and 5 (Xiong et al., 2007). It is noticed that the raw EAF slag have bigger pore structure, 1.55$2.12 \mu \mathrm{m}$ and after adsorption, the pore size have been reduced to $0.17-0.40 \mu \mathrm{m}$, where the manganese has attached to it due to its surface chemistry.

Equilibrium isotherms: Adsorption isotherms describe how adsorbates interact with adsorbents and so are important in optimizing the use of adsorbents. Therefore, the equilibrium data obtained is essential for the design of sorption system to remove manganese from effluents. Two isotherm models are described, i.e. the Langmuir and the Freundlich models (Yang, 2003; Tchobanoglous and Burton, 1991).

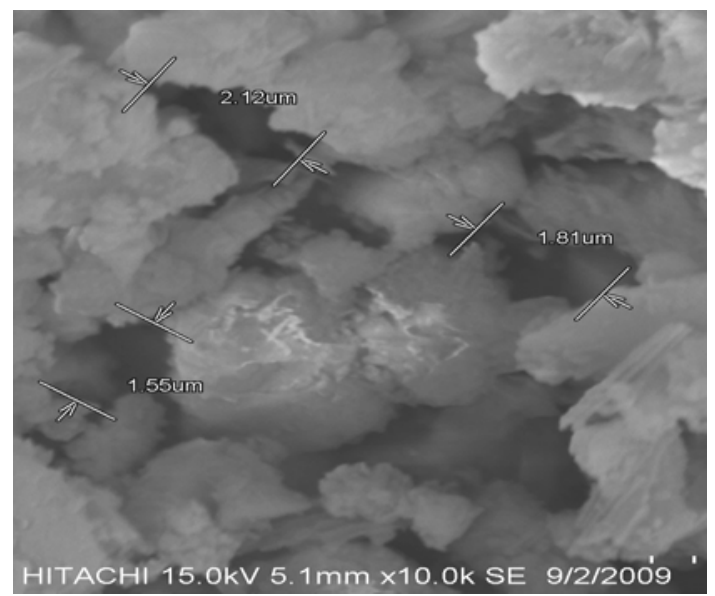

Fig. 4: SEM image of raw EAF Slag before adsorption 


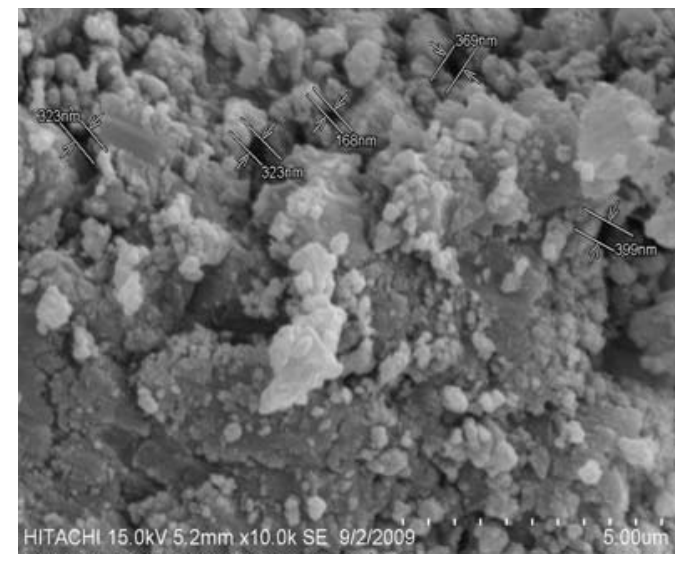

Fig. 5: SEM image of raw EAF slag after adsorption, $5 \mathrm{~h}$ for $\mathrm{C}_{6}, 120 \mathrm{mg} \mathrm{L}^{-1}$ manganese solution

The Langmuir isotherm was originally proposed to describe the adsorption of the gas molecules onto metal surfaces. However, it has found successful applications in many other real sorption processes of monolayer adsorption. The Langmuir isotherm model predicts the existence of monolayer coverage of the adsorbate at the outer surface of the adsorbent. The isotherm equation assumes also that adsorption takes place at specific homogeneous sites within the adsorbent. It is then assumed that once a manganese molecule occupies a site, no further adsorption can take place at that site. Moreover, the Langmuir equation is based on the assumption of a structurally homogeneous adsorbent where all sorption sites are identical and energetically equivalent (Wong et al., 2003b). The Langmuir equation can be represented by the following expression:

$$
\mathrm{q}_{\mathrm{e}}=\frac{\mathrm{Q}_{\mathrm{m}} \cdot \mathrm{K}_{\mathrm{L}} \cdot \mathrm{C}_{\mathrm{e}}}{1+\mathrm{K}_{\mathrm{L}} \cdot \mathrm{C}_{\mathrm{e}}}
$$

where, $C_{e}$ is the equilibrium concentration of manganese ions, $\mathrm{Q}_{\mathrm{m}}\left(\mathrm{mg} \mathrm{g}^{-1}\right)$ is the maximum adsorption capacity and $\mathrm{K}_{\mathrm{L}}$ is Langmuir constant related to energy of the adsorption. The Langmuir equation can be linearized:

$$
\frac{\mathrm{C}_{\mathrm{e}}}{\mathrm{q}_{\mathrm{e}}}=\frac{1}{\mathrm{~K}_{\mathrm{L}} \cdot \mathrm{Q}_{\mathrm{m}}}+\frac{1}{\mathrm{Q}_{\mathrm{m}}} \cdot \mathrm{C}_{\mathrm{e}}
$$

The Freundlich equation is an empirical equation employed to describe heterogeneous systems, in which it is characterized by the heterogeneity factor $1 / \mathrm{n}$. Hence, the Freundlich equation can be expressed as:

$\mathrm{q}_{\mathrm{e}}=\mathrm{K}_{\mathrm{F}} \cdot \mathrm{C}_{\mathrm{e}}^{1 / n}$

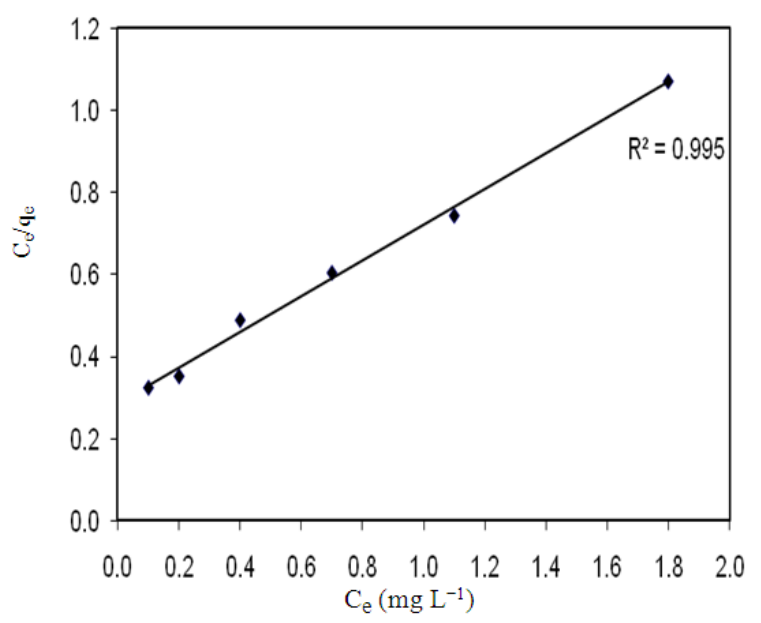

Fig. 6: Langmuir isotherm of manganese solution at constant temperature of $28^{\circ} \mathrm{C}$

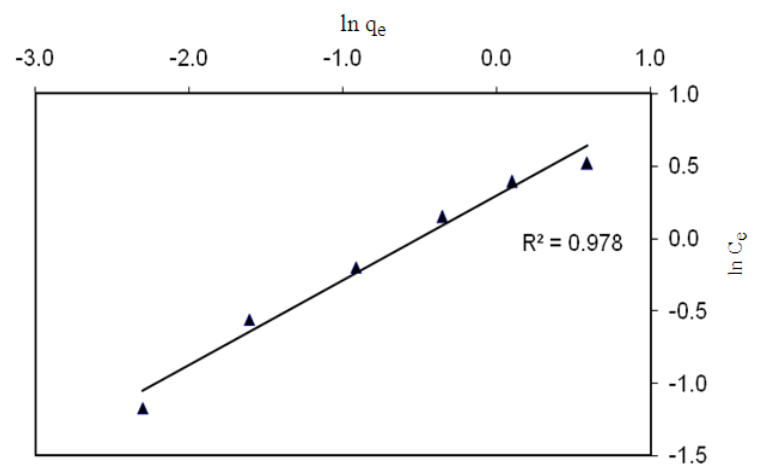

Fig. 7: Freundlich isotherm of manganese solution at constant temperature of $28^{\circ} \mathrm{C}$

Table 4: Parameters of Langmuir and Freundlich isotherm models

\begin{tabular}{llllll}
\hline Langmuir isotherm & & \multicolumn{3}{l}{ Freundlich isotherm } \\
\hdashline $\mathrm{Q}_{\mathrm{m}}$ & $\mathrm{K}_{\mathrm{L}}$ & $\mathrm{R}^{2}$ & $\mathrm{~K}_{\mathrm{F}}$ & $\mathrm{n}$ & $\mathrm{R}^{2}$ \\
\hline 2.31 & 1.50 & 0.995 & 1.19 & 1.34 & 0.978
\end{tabular}

where, $\mathrm{K}_{\mathrm{F}}$ is Freundlich constant $\left(\mathrm{dm}^{3} \mathrm{~g}^{-1}\right)$ and $1 / \mathrm{n}$ is the heterogeneity factor. The Freundlich equation can be linearized:

$\operatorname{lnq}_{\mathrm{e}}=\frac{1}{\mathrm{n}} \ln \mathrm{C}_{\mathrm{e}}+\ln \mathrm{K}_{\mathrm{F}}$

The equilibrium data yielded good linear plots with both Langmuir isotherm (Fig. 6, regression coefficient 0.995 ) and Freundlich isotherm (Fig. 7, regression coefficient 0.978 ). The isotherm parameters computed from the plots are given in Table 4. The Langmuir isotherm was found to best describe the adsorption data 
as compared to Freundlich isotherm. The maximum uptake $\mathrm{Q}_{\mathrm{m}}$ is $2.31 \mathrm{mg}$ of manganese per gram of slag and the Langmuir constant $\mathrm{K}_{\mathrm{L}}$ is $1.50(1 / \mathrm{mg})$.

It is observed that the $\mathrm{pH}$ of the solution will be slightly increased from 7-8 due to the formation of $\mathrm{CaOH}$ from $\mathrm{CaO}$ present in the slag.

\section{CONCLUSION}

This analysis shows that the EAF slag is an effective adsorbent for manganese. The adsorption time required to reach equilibrium varies from 3-4 $\mathrm{h}$ for different initial concentration of $10-120 \mathrm{mg} \mathrm{L}^{-1}$. For the adsorption kinetic study, it is found that the kinetic can be described well by the pseudo-2nd order model with fairly high correlation coefficients. In addition, Langmuir isotherm was found to describe well the isotherm data, with Langmuir constant of $1.50(1 / \mathrm{mg})$ and maximum uptake of $2.31 \mathrm{mg} \mathrm{g}^{-1}$. It can be concluded that the EAF slag, a steel plant residue which is abundant and easily obtained at low cost, can be used for manganese removal in waste water treatment and related industry.

\section{ACKNOWLEDGEMENT}

The researchers would like to thank Southern Steel Berhad for the supply of EAF slag.

\section{REFERENCES}

Chuah, T.G., A. Jumasiah, I. Azni, S. Katayon and S.Y.T. Choong, 2004. Rice husk as a potentially low cost biosorbent for heavy metal and dye removal: An overview. Desalination, 175: 305-316. DOI: $10.1016 /$ j.desal.2004.10.014

Hamadi, N.K., S. Swaminathan and X.D. Chen, 2004. Adsorption of Paraquat dichloride from aqueous solution by activated carbon derived from used tires. J. Hazard. Mater., 112: 133-141. DOI: 10.1016/j.jhazmat.2004.04.011

Kim, D.H., M.C. Shin, H.D. Choi, C.I. Seo and K.T. Baek, 2007. Removal mechanisms of copper using steel making slag: Adsorption and precipitation. Desalination, 223: 283-289. DOI: 10.1016/j.desal.2007.01.226
Nehrenheim, E. and J.P. Gustafsson, 2007. Kinetic sorption modelling of $\mathrm{Cu}, \mathrm{Ni}, \mathrm{Zn}, \mathrm{Pb}$ and $\mathrm{Cr}$ ions to pine bark and blast furnace slag by using batch experiments. Bioresour. Technol., 99: 1571-1577. DOI: 10.1016/j.biortech.2007.04.017

Ortiz, N., M.A.F. Pires, J.C. Bressiani, 2000. Use of steel converter slag as nickel adsorber to waste watertreatment. Waste Manage., 21:631-635.

Tchobanoglous, G. and F.L. Burton, 1991. Wastewater Engineering: Treatment, Disposal and Reuse. 3rd Edn., McGraw-Hill, New York, ISBN: 0071008241, pp: 1334.

Wong, K.K., C.K. Lee, K.S. Low and M.J. Haron, 2003a. Removal of $\mathrm{Cu}$ and $\mathrm{Pb}$ from electroplating wastewater using tartaric acid modified rice husk. Process Biochem., 39: 437-445. DOI: 10.1016/S0032-9592(03)00094-3

Wong, Y.C., Y.S. Szeto, W.H. Cheung and G. Mckay, 2003b. Adsorption of acid dyes on chitosanequilibrium isotherm analyses. Process Biochem., 39: 695-704. DOI: 10.1016/S0032-9592(03)00152-3

Xiong, J., Z. He, Q. Mahmood, D. Liu, X. Yang and E. Islam, 2007. Phosphate removal from solution using steel slag through magnetic separation. J. Hazard. Mater., 152: 211-215. DOI: 10.1016/j.jhazmat.2007.06.103

Xue, Y. J., H.B. Hou and S.J. Zhu, 2008a. Competitive adsorption of copper(II), cadmium(II), lead(II) and zinc(II) onto oxygen furnace slag. J. Hazard. Mater., 162 : 391-401. DOI: 10.1016/j.jhazmat.2008.05.072

Xue, Y.J., H.B. Hou and S.J. Zhu, 2008b. Adsorption removal of reactive dyes from aqueous solution by modified basic oxygen furnace slag: Isotherm and kinetic study. Chemical Eng. J., 147: 272-279. DOI: $10.1016 /$ j.cej.2008.07.017

Yang, R.T., 2003. Adsorbents: Fundamentals and Applications. 1st Edn., Wiley-Interscience, New Jersey, ISBN: 0-471-29741-0, pp: 424. 